\title{
Genetic Polymorphisms of the Dopamine and Serotonin Systems in Schizophrenia in Relation to Violence and Aggression
}

\author{
Vjekoslav Peitl| ${ }^{1,2}$, Iva Ivančić Ravlić ${ }^{1}$, Vedrana Golubić Zatezalo ${ }^{1}$ \\ ${ }^{1}$ Department of Psychiatry, University Hospital Center Sestre Milosrdnice, Zagreb, \\ Croatia, ${ }^{2}$ Catholic University of Croatia, Zagreb, Croatia
}

\begin{abstract}
Schizophrenia is a chronic disorder that ultimately leads to a decline in cognitive, social and emotional functioning. Although the aetiology of the disorder is still unknown, it is most likely multifactorial, with equal importance of environmental and genetic factors. It has been hypothesized that those same factors influence aggressive symptomatology and possibly even violence in schizophrenia. The association between schizophrenia and aggressive behaviour is well documented; however, the impact of genetic alterations and gene polymorphisms on the incidence and type of violence in this group of patients has rarely been the focus of scientific research. Both violence and aggression are complex behavioural patterns that lead to difficulties in the comparability of genetic studies and limits their clinical applicability. In this review paper we systematically presented findings from studies examining the association between gene polymorphisms of the dopamine and serotonin systems and aggressive symptoms and violent behaviour in schizophrenia.
\end{abstract}

Key words: dopamine, serotonin, genetic polymorphism, aggression, violence

Copyright $\odot 2020$ KBCSM, Zagreb

e-mail: alcoholism.kbcsm@gmail.com•www.http://apr.kbcsm.hr

\section{Introduction}

Schizophrenia is a chronic disorder with recurrent course and a variety of different clinical presentations. It is characterized by acute episodes followed by periods of partial or complete remissions, with every exacerbation leading to a decline in cognitive and emotional functioning in the long run

\section{Correspondence to:}

Vjekoslav Peitl, MD, PhD,

Departmentof Psychiatry, University Hospital Centre Sestre mi-

losrdnice,

Vinogradska c. 29, 10000 Zagreb, Croatia

E-mail: vjekoslav.peitl@gmail.com
[1]. Since there is no biological marker or a laboratory test which would help diagnose schizophrenia it is currently diagnosed by using a set of defined descriptive criteria. The most commonly used criteria are the $10^{\text {th }}$ revision of the International Classification of Diseases (ICD-10) by the World Health Organization [2] and the fifth edition of the Diagnostic and Statistical Manual of Mental Disorders (DSM-5) of the American Psychiatric Association [3].

For years classical psychiatric practice has used the dichotomous division of schizo- 
phrenia symptoms into positive and negative, which usually resulted in neglecting other symptom domains or combining them with the positive and negative symptoms. Multidimensional concept of schizophrenia allows grouping of symptoms into five clusters: positive, negative, cognitive, affective or depressive and aggressive $[1,4]$. Since aggressive or hostile symptoms can be found in other psychiatric disorders (bipolar affective disorder, personality disorders, dementia, attention deficit hyperactivity disorder, etc.) and some somatic disorders, they are not specific to schizophrenia. These symptoms include hostility, self-harm, property damage, arson and sexual impulsivity $[1,5]$. One of the major public health problems is violence and especially when caused by psychiatric patients [6]. Although most psychiatric patients are not violent, an epidemiological study in 1990 found significant association between schizophrenia and an increased risk of violent behaviour [7]. Current American Psychiatric Association practice guidelines for the treatment of patients with schizophrenia suggest that identifying risk factors for violence and assessment of dangerousness are parts of a standard psychiatric evaluation, which should be conducted in a safe environment [8].

Swedish study, which included 24,297 patients diagnosed with schizophrenia from 1972 to 2009 , has shown that $10.7 \%$ of men and $2.7 \%$ of women had been convicted of a violent offense within the first five years of diagnosis. These patients had an increased risk of death with $3.3 \%$ of men and $2 \%$ of women dying prematurely of any cause. The odds ratio for the negative outcome was 7.5 in men and 11.1 in women compared to the general population. During the follow-up, the ratio increased over time compared to the siblings of the patients in the follow up [9].
Most patients with schizophrenia (72\%) who commit a crime do so before the first contact with a psychiatrist. A meta-analysis published in 2011 has shown that $35 \%$ of patients with a first psychotic episode had previously committed at least one offence [10]. Meta-analysis by Nielssen and Large also demonstrated by that patients who had a first psychotic episode (before treatment) had 15.5 times higher risk of homicide than the general population [11].

There is a number of factors associated with an increased risk of violence which are well known, some of which are related to psychotic symptoms such as hallucinations or delusions, while others are related to comorbidities or demographic factors. The most important risk factors associated with psychosis are untreated psychotic symptoms, especially persecutory delusions and the Capgras syndrome. Comorbidities include substance abuse, antisocial personality disorders and mood disorders, although anxiety and negative symptoms have been shown to reduce the risk of violence. Other risk factors include hostility, poor social skills, a history of violence or history of physical or sexual abuse. Although low levels of intelligence are associated with the violence of psychotic patients, the level of intelligence by itself is not a predictor since, for example, many violent paranoid patients are above average intelligent [12]. Key demographic factors include male gender, younger age, low socioeconomic status, life in a poorer setting, and being a child of a father with a history of substance abuse or abandonment by father before the age of 15 . Systematic review of the risk of violence in schizophrenia and other psychoses performed by Fazel and associates in 2009 found that comorbidity with substance use disorders substantially increased the risk of 
violence. However, this study also suggests that individuals with substance use disorders may be more dangerous than patients with schizophrenia (or other psychoses) without comorbid substance abuse. In other words, psychoses comorbid with substance abuse confer no additional risk over the risk associated with the substance abuse alone [13].

Modern brain imaging techniques can identify the structural and functional abnormalities associated with violence in patients with schizophrenia, but in most cases these findings are still common to all violent offenders [12]. In patients with schizophrenia with a history of violence or high aggression scores the most common findings were reduced volumes of the hippocampus and the frontal lobe which suggests that dysfunction of fronto-limbic regions in schizophrenia may be associated with aggression or violence [14].

Although many reports address the link between violence and schizophrenia, only a small number of studies have addressed the possible link between genetic changes or gene polymorphisms and aggression in schizophrenia. In this review, we aimed to focus on the association between commonly studied gene polymorphisms and aggressive symptoms of schizophrenia. We have examined studies published and available on PubMed and Scopus, while summarizing the results of different original studies and meta-analyses. Our search of MeSH terms: schizophrenia, aggression/violence and gene/polymorphisms yielded a total of 46 , however due to repetition a total of 34 studies were finally included in this review.

\section{Findings from genetic studies}

The incidence of schizophrenia is known to be significantly higher in certain fami- lies than in the general population, suggesting that there is some form of inheritance. Unlike in monogenetic diseases, in which a certain genotype leads to a disease in almost all cases, in schizophrenia the correlation between genotype and phenotype is significantly weaker. It is generally accepted that heritability (a genetic contribution to the observed phenotypic variance) in schizophrenia ranges between 64 and $81 \%$. Children of parents with schizophrenia are ten times more likely to develop the disease than the general population. Risk of the disease in a family of a schizophrenic patient declines significantly faster than the proportion of genes they share, suggesting that classic (Mendelian) model of inheritance may not apply here. Despite its high heritability, most cases of the disease are still sporadic. The low prevalence of the disease (which is about $1 \%$ in schizophrenia) combined with high heritability and occurrence of more sporadic than familial cases of the disease primarily corresponds to the polygenic inheritance model $[15,16]$.

Twin studies conducted on patients with schizophrenia and their siblings have shown that genotype contributes to less than $50 \%$ of the etiology of the disease. Therefore, many environmental factors are being tested as a trigger for the development of the disease in a predisposed individual. Epidemiological studies indicate a number of factors associated with an increased risk of developing schizophrenia such as prenatal infection and activation of the immune system, father's age, malnutrition, obstetric complications leading to hypoxia, social stress in childhood and adolescence, and cannabis abuse. The multihit model suggests a person is particularly sensitive to exposure to adverse environmental events, which could eventually trigger biological consequences associated 
with schizophrenia, in two time periods of life, specifically, during early development of brain and during its maturation during adolescence [17].

Numerous genetic studies have examined the gene candidates possibly responsible for the development of schizophrenia. Some of the genes tested are neuregulin 1 (localized on chromosome 8p), dysbindin (chromosome $6 \mathrm{p}$ ), activator of D-amino acid oxidase (chromosome 13), disrupted in schizophrenia 1 (DISC1) (chromosome 1), neurogranin, genes of the major histocompatibility complex and several others. The genes regulating the serotonergic and catecholaminergic systems are key candidates for genetic basis of human aggression [14]. The most commonly studied genes and their polymorphisms associated with violence in schizophrenia are the genes for catechol-o-methyltransferase (COMT), serotonin transporter (SERT), monoamino oxidase A (MAO-A), and brainderived neurotrophic factor (BDNF) [18].

\section{Catechol-o-methyltransferase (COMT)}

COMT is a tissue-nonspecific enzyme responsible for the degradation of dopamine. It was first described in 1958 by Axelrod and associates. COMT catalyses the transfer of the coenzyme methyl group S-adenosyl-Lmethionine (AdoMet) to one of the hydroxyls of the catecholamine in the presence of magnesium. By catalysing this methylation, COMT leads to the inactivation of catecholamine neurotransmitters such as dopamine, noradrenaline and adrenaline and catechol drugs such as levodopa [19].

The COMT gene is located on chromosome $22 \mathrm{q} 11.2$ and has been considered as a potential susceptibility gene for schizophrenia. It is also considered relevant in the search for a neurobiological basis for aggression in schizophrenia patients. There are significant variations in enzymatic activity due to common genetic polymorphisms of the COMT gene. Functional polymorphism (valine [Val] or methionine [Met]) at codon 108 determines enzymatic activity (Val158Met polymorphism). The Met allele is less stable and has 3 to 4 times lower biological activity than the Val allele. Persons with two copies of the Met allele or a deletion are thought to have correspondingly higher levels of dopamine in certain regions of the brain, especially in the prefrontal cortex.

In 1997, Strous and associates evaluated 37 patients with schizophrenia based on a history of violent and threatening behaviour, crimes committed, cocaine and alcohol abuse as well as other antisocial behaviour. The aforementioned group of authors found an association between low COMT activity polymorphisms and a higher risk for aggressive and dangerous behaviour compared to patients who were homozygous for high activity [20]. Furthermore, Gogos and associates demonstrated a significant influence of COMT in some aspects of emotional and social behaviour on the knockout mouse model. Male mice which were heterozygotes for COMT deficiency have shown significantly increased aggression [21].

Over the following years, several studies have also demonstrated the association of the Met allele with an increased risk of violence in schizophrenia patients [22-28]. Contrary to previous findings, in 2001 Jones and associates demonstrated a significant difference between homozygotes for the high activity genotype of COMT and heterozygotes, while there was no difference between homozygotes for high and low activity. The authors state that their result is a possible ex- 
ample of heterosis, where heterozygosity is a protective factor against a violent behaviour. It also needs to be emphasized that several studies have not demonstrated an association of COMT gene polymorphism with violent behaviour in schizophrenia [29-32]. In 2012, Bhakta and associates performed a metaanalysis which covered all previous studies on the association between COMT Met158 alleles and violence in schizophrenia [33]. The results of the meta-analysis suggest that men with the Met allele, that is, low COMT activity, are at increased risk of violent behaviour. As patients included in the studies of the meta-analysis were mostly men $(80 \%)$, the power to detect relationship of COMT activity and violence in women was limited. Same year, Singh and colleagues published another meta-analysis which has shown that men with least one Met allele have approximately 50\% higher risk of violent behaviour compared to individuals homozygous for the Val allele. No significant association was found between the presence of the Met allele and violence in women or when the outcome was limited to homicides. On a group of 591 subjects, 300 of whom were patients with schizophrenia and the other 291 healthy volunteers of the control group, our group of authors did not demonstrate an association between COMT polymorphisms and aggressive symptoms in schizophrenia as measured by the PANSS scale [34].

\section{Monoamino oxidase (MAO)}

MAO is a mitochondrial-bound enzyme that catalyses the oxidative deamination of dietary amines, monoamine neurotransmitters and hormones. This broad spectrum of substrates includes several significant biogenic molecules: indolamines such as serotonin (5-hydroxytryptamine, 5-HT) and tryptamine; catecholamines, such as dopamine, noradrenaline and adrenaline; and trace amines, such as beta phenylethylamine (PEA), tyramine and octopamine. Rapid degradation of brain monoamines is crucial for the proper function of synaptic neurotransmission. Monoaminergic signalling is considered to be one of the key mechanisms in modulation of mood and emotions, as well as for control of motor, perceptual and cognitive functions. There are two different types of MAO, named $A$ and $B$, which have shown difference in sensitivity to their substrates and inhibitors. MAO-A shows a greater affinity for serotonin and noradrenaline, while MAO-B prefers PEA and other trace amines. Both enzymes contribute similarly to the metabolism of dopamine and other monoamines. The genes for both enzymes are located on the short arm of chromosome X (Xp11.23) [35]. Among the genes tested for predisposition to violence, the key role of the MAOA gene encoding the MAO-A enzyme is increasingly emphasized. The role of MAO-A in the neurobiological basis of violence has also been confirmed by preclinical studies. Studies on MAOA knockout mice have shown that the deficiency of this enzyme leads to marked aggression, maladaptive defensive reactivity, impaired information processing and repetitive responses [36]. The loss of function mutation of the MAOA gene results in Brunner's syndrome characterized by an exaggerated tendency to violent behaviour in response to minor stressors [37]. A functional polymorphism located in the promoter region of the MAOA gene (uVNTR) is characterized by a tandem repeat variable number (VNTR) of 30 base pairs expressing five alleles of 2, 3, 3.5, 4, and 5 copies [38]. These 
polymorphisms have been studied in patients with schizophrenia and aggressive behaviour.

A study performed by Zammit and associates in 2004 failed to demonstrate an association between MAO-A gene polymorphisms and aggressive behaviour as measured by the overt aggression scale in a group of $346 \mathrm{pa}-$ tients with schizophrenia [31]. Another study conducted in 2007 by Fresan and associates, on a sample of 71 patients, also did not demonstrate an association between MAO-A genes and aggressive behaviour in schizophrenic patients. However, in this study, by analysing aggression against the OAS scale, a significant association between the 4R allele and verbal aggression was demonstrated [39]. An association study and meta-analysis of 373 psychiatric patients, 164 of whom were diagnosed with schizophrenia, did not demonstrate an association between MAOA-uVNTR and suicidal behaviour in neither the whole group nor in a group of patients with schizophrenia [40]. Contrary to these findings, in a sample of 300 patients with schizophrenia our group of authors has previously established an association between this MAOA polymorphism and aggressive/ impulsive symptoms (as well as negative symptoms) [41].

\section{Serotonin transporter (SERT)}

SERT has a crucial role in modulating the amount of serotonin (5-HT) in the synapse by controlling intake to the presynaptic terminals. The gene encoding human SERT is located on chromosome $17 \mathrm{q} 12$ and has a polymorphism in the 5' promoter region of the gene (5HT'TLPR), more specifically, insertion or deletion of $44 \mathrm{bp}$ leading to a long allele " $\mathrm{L}_{\mathrm{A}}$ " with high transcriptional activity or " $\mathrm{L}_{\mathrm{G}}$ " and short " $\mathrm{S}$ " allele which both have lower transcriptional activity. Rates of SERT are decreased in the brain or platelets of suicidal patients and suicide attempters, in the brain of patients with impulsive violent behaviour, and the level of SERT in platelets is inversely related to aggression in patients with personality disorders $[42,43]$.

In a French study of 185 patients with schizophrenia there was a higher incidence of genotypes containing a low activity allele in those who attempted a violent suicide compared to those who attempted suicide by a non-violent means. No evidence of an association with schizophrenia alone or with impulsivity was found compared with the control group [42]. Hung and associates found that male Chinese patients, carriers of the $\mathrm{L}_{\mathrm{A}}$ allele were significantly more likely to attempt suicide or attempt suicide by violent means compared to the control group. However, no association was found when examining the results through traditional biallelic 5-HTTLPR methods [44]. It is interesting to mention a case of a highly aggressive schizophrenic patient of Libyan Jewish origin who ultimately committed suicide. Molecular analysis demonstrated the long $(\mathrm{L})$ and short $(\mathrm{S})$ alleles of the 5-HT'TLPR polymorphism, however, the short allele was composed of 13 repeating units, i.e. 23 base pairs shorter than the standard short allele. This unusual allele was not detected in any DNA sample of a control group consisting of 172 healthy individuals and 361 patients with various psychiatric illnesses, including 150 patients with schizophrenia [45].

Other serotonergic polymorphisms have been investigated rarely, mostly resulting in negative associations. In a study performed on 115 Chinese patients examined a role of serotonin $2 \mathrm{~A}$ receptor polymorphisms (HTR2A) in modulating emotional manage- 
ment in schizophrenia. Heterozygotes of the A/G genotype were shown to have better emotional control than the $G / G$ homozygotes, but not and A/A ones. This suggests a role for HTR2A gene variation in emotional regulation, which, if disrupted, could lead to aggressive behaviour [43]. Also, it is worth noting that no association was found between aggressive behaviour in schizophrenia and the A218C polymorphism of tryptophan hydroxylase 1 gene [46], nor the serotonin 1B receptor (A161T) gene polymorphism [47].

\section{Brain-derived neurotrophic factor (BDNF)}

BDNF is a type of nerve growth factors, which is highly expressed in the adult brain and plays a crucial role in the development, survival and functional maintenance of neurons. BDNF is an essential modulator of synaptic transmission and plasticity in the central nervous system and is involved in cognitive processes such as memory and learning. Animal model studies suggest that changes to the BDNF gene could be involved in aggressive behaviour [48,49].

In a study of 118 Italian patients, the association of the Val66Met BDNF gene polymorphism with the aggressive behaviour of schizophrenia patients was examined. $\mathrm{Pa}$ tients with the Met/Val genotype were significantly more aggressive compared to those with the $\mathrm{Val} / \mathrm{Val}$ genotype, as measured by the modified overt aggression scale (MOAS). Analysing the MOAS subscales authors found that overt physical aggression mainly contributed to this result. These findings are in contrast to studies conducted in Chinese and Korean patients where no association was found between Val66Met polymorphism and aggressive behaviour of patients with schizophrenia [50,51].

\section{Methylenetetrahydrofolate reductase (MTHFR)}

MTHFR is an enzyme involved in the folate metabolism pathway which catalyses conversion of methylenetetrahydrofolate to methyltetrahydrofolate, the primary circulating form of folate. Reduced MTHFR activity is associated with impaired folate processing leading to a decrease of folate levels in blood. Circulating folate is a co-substrate for the remethylation of homocysteine into methionine which is a precursor of S-adenosylmethionine (SAM), a major donor of the methyl group. Variants of the MTHFR gene and different levels of circulating folate have important influence DNA methylation and gene regulation. Defects in remethylation and transsulfuration of homocysteine to cysteine are associated with an elevated level of total plasma homocysteine [52]. MTHFR gene polymorphisms rs1801131 and rs1801133 are associated with decreased enzymatic activity, leading to increased plasma homocysteine levels. Higher plasma homocysteine may lead to subcortical limbic hyperactivity, which affects the occurrence of aggressive behaviour.

To the best of our knowledge a single study examined the association of aggressive behaviour in schizophrenia and MTHFR gene polymorphisms. Dong and associates have shown that the T-allele polymorphism rs1801133 and the T-C haplotype polymorphism rs1801131 are associated with aggressive behaviour in Chinese patients with schizophrenia [53].

\section{Neurogranin (NRGN)}

NRGN gene is considered an important candidate gene for development of schizophrenia due to its function and location. Genome-wide linkage studies found an as- 
sociation of chromosome 11q23.3-24 with schizophrenia, and NRGN is located on chromosome 11q24.2 which is consistent with this chromosomal region. NRGN encodes a substrate for postsynaptic protein kinase $\mathrm{C}$ that binds to calmodulin (CaM) in the absence of calcium. NRGN also regulates $\mathrm{CaM}$ release and activation of $\mathrm{CaM}-\mathrm{Ca} 2+$ dependent enzymes, mediating the N-methyl-D-aspartate (NMDA) signalling pathway, which plays an important role in the learning and memory neuroplasticity. It is also involved in the pathophysiology of glutamate in schizophrenia.

So far, only one study has examined the association of polymorphisms of this gene with violence in schizophrenia. In 2015, $\mathrm{Su}$ and associates demonstrated that the CC genotype of the rs12807809 polymorphism is associated with a higher score in the PANSS aggression and activation subscales than the other genotypes. Also, Han Chinese with schizophrenia, carriers of the $\mathrm{C}$ allele of the rs12807809 polymorphism, had higher scores of general, activation, depression, aggression, and global symptoms than carriers of the T allele [54].

\section{Dopamine receptor 4 gene (DRD4)}

Dopamine receptors are involved in a number of neurological processes such as cognition, memory, learning, motor control, as well as in the modulation of neuroendocrine signalling. They are also associated with numerous neurological and psychiatric disorders. DRD4 is located close to the telomere of the chromosome $11 \mathrm{p}$. It has a variable number of tandem repeats polymorphism of the 48 base pairs in the third exon. Repetitions range from 2 to 11 times, with the most common variants being $2(2 \mathrm{R}), 4$ (4R) and 7
(7R) repetitions. The frequency of variants varies greatly between ethnic groups. These variations affect the function of the receptor itself, and the 7-repetition allele encodes a receptor with a lower affinity for dopamine [55]. In 2005, Fresan and associates demonstrated the association of this polymorphism with aggression in patients with schizophrenia. Also, the frequency of carriers of the $7 \mathrm{R}$ allele was higher in the aggressive group compared to the control group. Analysis of the OAS scale revealed that carriers of DRD4$7 \mathrm{R}$ alleles had a significantly higher score in physical aggression toward others than carriers of other alleles [39].

\section{Tumor necrosis factor receptor 1 (TNFR1)}

Tumor necrosis factor alpha $(\mathrm{TNF} \alpha)$ is an important susceptibility gene for schizophrenia as elevated $\mathrm{TNF} \alpha$ levels have been demonstrated in patients with schizophrenia. It exerts its activity through TNFR1 and TNFR2, which are constitutively expressed on all types of neural cells. TNFR1 plays an important role in inducing various cellular responses, such as cell death, differentiation or inflammation. In patients with schizophrenia, there is an increase in brain and serum TNFR1 levels over time, and an association between TNFR1 levels and the severity of schizophrenia symptoms has been demonstrated.

A study of 388 Polish patients with paranoid schizophrenia matched with 657 healthy controls demonstrated an association between intensity of excitement symptoms measured by the PANSS scale and rs4149577 and rs1860545 polymorphisms in male patients. This also resulted in increased risk of violent behaviour and non-adherence to psychopharmacotherapy [56]. 


\section{Conclusion}

Schizophrenia is a complex chronic disorder characterized by heterogeneous clinical features whose etiology is not fully understood, though it is well known that various environmental and social factors may contribute to the development of the disease in predisposed individuals. Due to insufficient understanding of the biological basis of schizophrenia, there are currently no biochemical markers that would help us define a diagnosis of schizophrenia, and it is still diagnosed based on classical descriptive criteria. Numerous studies have sought to determine the genetic basis of the disorder, demonstrating the association of numerous genes and their polymorphisms with the development of schizophrenia and making it clear that it will not be possible to detect a unique genetic aberration for such a heterogeneous disease. Studies focusing on one or several symptom clusters of schizophrenia faced the same problem, with ambiguous findings. Aggressive symptoms in schizophrenia are no exception, even though numerous studies have established an association between schizophrenia and violent behaviour, there are relatively few of them that have addressed the role of genetics in the aggressive behaviour of patients with schizophrenia. Since aggression is an extremely complex form of behaviour which can be manifested in several

\section{References}

1. Sadock B, Sadock V, Ruiz P. Kaplan and Sadock's Synopsis of Psychiatry: Behavioral Sciences/Clinical Psychiatry, eleventh edition. Philadelphia: Lippincott Williams and Wilkins; 2014.

2. Svjetska zdravstvena organizacija. Klasifikacija mentalnih poremećaja i poremećaja ponašanja: different ways, there is no single established definition of aggression, which makes it impossible to compare similar studies. Despite the complexity of genetic research, environmental and epigenetic factors which contribute to the development of both schizophrenia itself and complex behavioural patterns such as aggression are often not considered. All above stated limits the applicability of genetic testing in routine clinical practice. Unambiguous definition of aggression, environmental factors, and epigenetic changes for the purpose of genetic research on schizophrenia could contribute to the development of predictive models of violent behaviour and, consequently, the prevention thereof.

\section{Acknowledgments}

The research for this publication has been conducted within the framework of the Installation Research Project titled "Croatian Violence Monitor: A Study of the Phenomenology, Etiology, and Prosecution of Delinquent Violence with Focus on Protecting Particularly Vulnerable Groups of Victims", funded by the Croatian Science Foundation (UIP-05-2017-8876). See: www.violence-lab. $\mathrm{eu}$

\section{Conflict of interest}

None to declare.
MKB-10 - deseta revizija. Zagreb: Medicinska naklada; 1999, p. 73-110.

3. Diagnostic and Statistical Manual of Mental Disorders: DSM-5. Arlington, VA: American Psychiatric Association; 2013.

4. Meltzer HY, Bolo WV, Hechers SH, Fatemi SH. Schizophrenia. In: Ebert MH, Loosen PT, Nur- 
combe B, Leckman JF (Eds.). Current diagnosis and treatment psychiatry, second edition. New York: McGraw-Hill Professional Publishing; 2008, p 261-288.

5. Stahl SM. Essential psychopharmacology, Neuroscientific basis and practical applications; fourth edition. Cambridge, UK: Cambridge University Press; 2013, p. 79-128.

6. Hodgins S: Violent behaviour among people with schizophrenia: a framework for investigations of causes, and effective treatment, and prevention. Phil Trans R Soc Lond B Biol Sci. 2008;363:250518.

7. Swanson JW, Holzer CE, Ganju VK, Jono RT. Violence and psychiatric disorder in the community: evidence from the Epidemiologic Catchment Area surveys. Hosp Community Psychiatry. 1009;41:761-70.

8. Lehman AF, Lieberman JA, Dixon LB, McGlashan TH, Miller AL, Perkins DO, et al. American Psychiatric Association; Steering Committee on Practice Guidelines. Practice guideline for the treatment of patients with schizophrenia, second edition. Am J Psychiatry. 2004;161(Suppl 2):1-56.

9. Fazel S, Wolf A, Palm C, Lichtenstein P. Violent crime, suicide, and premature mortality in patients with schizophrenia and related disorders: a 38-year total population study in Sweden. Lancet Psychiatry. 2014;1:44-54.

10. Large MM, Nielssen O. Violence in first-episode psychosis: a systematic review and meta-analysis. Schizophr Res. 2011;125:209-20.

11. Nielssen O, Large M. Rates of homicide during the first episode of psychosis and after treatment: a systematic review and meta-analysis. Schizophr Bull. 2010;36:702-12.

12. Silverstein SM, Del Pozzo J, Roché M, Boyle D, Miskimen T. Schizophrenia and violence: realities and recommendations. Crime Psychol Rev. 2015;1:21-42.

13. Fazel S, Gulati G, Linsell L, Geddes JR, Grann M. Schizophrenia and violence: systematic review and meta-analysis. PLoS Med. 2009;6:e1000120.

14. Cho W, Shin WS, An I, Bang M, Cho DY, Lee SH. Biological Aspects of Aggression and Violence in Schizophrenia. Clin Psychopharmacol Neurosci. 2019;17:475-86.
15. Bergen SE, Petryshen TL. Genome-wide association studies (GWAS) of schizophrenia: does bigger lead to better results. Curr Opin Psychiatry. 2012;25:76-82.

16. Gejman PV, Sanders AR, Duan J. The role of genetics in the etiology of schizophrenia. Psychiatr Clin North Am. 2011;33:35-66

17. Moran P, Stokes J, Marr J, Bock G, Desbonnet L, Waddington J, et al. Gene Environment Interactions in Schizophrenia: Evidence from Genetic Mouse Models. Neural Plast. 2016;2016:2173748.

18. Soyka M. Neurobiology of aggression and violence in schizophrenia. Schizophr Bull. 2011;37:913-20.

19. Lang MV. Trends in schizophrenia research. Hauppauge, NY, US: Nova Biomedical Books; 2004. p. 47.

20. Strous RD, Bark N, Parsia SS, Volavka J, Lachman HM. Analysis of a functional catechol-O-methyltransferase gene polymorphism in schizophrenia: evidence for association with aggressive and antisocial behavior. Psychiatry Res. 1997;69:71-7.

21. Gogos JA, Morgan M, Luine V, Santha M, Ogawa S, Pfaff D, et al. Catechol-O-methyltransferase-deficient mice exhibit sexually dimorphic changes in catecholamine levels and behavior. Proc Natl Acad Sci U S A. 1998;95:9991-6.

22. Lachman HM, Nolan KA, Mohr P, Saito T, Volavka J. Association between catechol O-methyltransferase genotype and violence in schizophrenia and schizoaffective disorder. Am J Psychiatry. 1998;155:835-7.

23. Kotler M, Barak P, Cohen H, Averbuch IE, Grinshpoon A, Gritsenko I, et al. Homicidal behavior in schizophrenia associated with a genetic polymorphism determining low catechol O-methyltransferase (COMT) activity. Am J Med Genet. 1999;88:628-33.

24. Strous RD, Nolan KA, Lapidus R, Diaz L, Saito T, Lachman HM. Aggressive behavior in schizophrenia is associated with the low enzyme activity COMT polymorphism: a replication study. Am J Med Genet B Neuropsychiatr Genet. 2003;120:2934.

25. Han DH, Park DB, Na C, Kee BS, Lee YS. Association of aggressive behavior in Korean male schizophrenic patients with polymorphisms in the serotonin transporter promoter and catechol- 
amine-O-methyltransferase genes. Psychiatry Res. 2004;129:29-37.

26. Han DH, Kee BS, Min KJ, Lee YS, Na C, Park DB, et al. Effects of catechol-O-methyltransferase Val158Met polymorphism on the cognitive stability and aggression in the first-onset schizophrenic patients. Neuroreport. 2006;17:95-99.

27. Hong JP, Lee JS, Chung S, Jung J, Yoo HK, Chang $\mathrm{SM}$, et al. New functional single nucleotide polymorphism (Ala72Ser) in the COMT gene is associated with aggressive behavior in male schizophrenia. Am J Med Genet B Neuropsychiatr Genet. 2008;147:658-60.

28. Tosato S, Bonetto C, Di Forti M, Collier D, Cristofalo D, Bertani M, et al. Effect of COMT genotype on aggressive behavior in a community cohort of schizophrenic patients. Neurosci Lett. 2011;495:17-21.

29. Liou YJ, Tsai SJ, Hong CJ, Wang YC, Lai IC. Association analysis of a functional catechol-Omethyltransferase gene polymorphism in schizophrenic patients in Taiwan. Neuropsychobiology. 2001;43:11-4.

30. Koen L, Kinnear CJ, Corfield VA, Emsley RA, Jordaan E, Keyter N, et al. Violence in male patients with schizophrenia: risk markers in a South African population. Aust N Z J Psychiatry. 2004;38:254-9.

31. Zammit S, Jones G, Jones SJ, Norton N, Sanders RD, Milham C, et al. Polymorphisms in the MAOA, MAOB, and COMT genes and aggressive behavior in schizophrenia. Am J Med Genet B Neuropsychiatr Genet. 2004;128:19-20.

32. Kim YR, Kim JH, Kim SJ, Lee D, Min SK. Catechol-O-methyltransferase Val158Met polymorphism in relation to aggressive schizophrenia in a Korean population. Eur Neuropsychopharmacol. 2008;18:820-5.

33. Bhakta SG, Zhang JP, Malhotra AK. The COMT Met158 allele and violence in schizophrenia: a meta-analysis. Schizophr Res. 2012;140:192-7.

34. Singh JP, Volavka J, Czobor P, Van Dorn RA. A metaanalysis of the Val158Met COMT polymorphism and violent behavior in schizophrenia. PLoS One. 2012;7:e43423.

35. Bortolato M, Chen K, Shih JC. Monoamine oxidase inactivation: from pathophysiology to therapeutics. Adv Drug Deliv Rev. 2008;60:1527-33.
36. Stetler DA, Davis C, Leavitt K, Schriger I, Benson $\mathrm{K}$, Bhakta S, et al. Association of low-activity MAOA allelic variants with violent crime in incarcerated offenders. J Psychiatr Res. 2014;58:69-75.

37. Brunner HG, Nelen M, Breakefield XO, Ropers $\mathrm{HH}$, van Oost BA. Abnormal behaviour associated with a point mutation in the structural gene for monoamine oxidase A. Science. 1993;262:578-80.

38. Camarena B, Fresán A, Aguilar A, Escamilla R, Saracco R, Palacios J, et al. Monoamine oxidase a and $\mathrm{B}$ gene polymorphisms and negative and positive symptoms in schizophrenia. ISRN Psychiatry. 2012;2012:852949.

39. Fresan A, Camarena B, Apiquian R, Aguilar A, Urraca $N$, Nicolini $H$. Association study of MAO$\mathrm{A}$ and DRD4 genes in schizophrenic patients with aggressive behavior. Neuropsychobiology. 2007;55:171-5.

40. Hung CF, Lung FW, Hung TH, Chong MY, Wu $\mathrm{CK}$, Wen JK, et al. Monoamine oxidase A gene polymorphism and suicide: an association study and meta-analysis. J Affect Disord. 2012;136:6439.

41. Peitl V, Štefanović M, Karlović D. Depressive symptoms in schizophrenia and dopamine and serotonin gene polymorphisms. Prog Neuropsychopharmacol Biol Psychiatry. 2017;77:209-15.

42. Bayle FJ, Leroy S, Gourion D, Millet B, Olié JP, Poirier MF, et al. 5HTTLPR polymorphism in schizophrenic patients: further support for association with violent suicide attempts. Am J Med Genet B Neuropsychiatr Genet. 2003;119:13-7.

43. Lo CH, Tsai GE, Liao CH, Wang MY, Chang JP, Tsuang HC, et al. Emotional management and 5-HT2A receptor gene variance in patients with schizophrenia. Biol Psychol. 2010;83:79-83.

44. Hung CF, Lung FW, Chen CH, O’Nions E, Hung TH, Chong MY, et al. Association between suicide attempt and a tri-allelic functional polymorphism in serotonin transporter gene promoter in Chinese patients with schizophrenia. Neurosci Lett. 2011;504:242-6.

45. Frisch A, Finkel B, Michaelovsky E, Sigal M, Laor N, Weizman R. A rare short allele of the serotonin transporter promoter region (5-HTTLPR) found in an aggressive schizophrenic patient of Jewish Libyan origin. Psychiatr Genet. 2000;10:179-83. 
46. Kim YR, Lee JY, Min SK. No evidence of an association between A218C polymorphism of the tryptophan hydroxylase 1 gene and aggression in schizophrenia in a Korean population. Yonsei Med J. 2010;51:27-32.

47. Hong CJ, Pan GM, Tsai SJ. Association study of onset age, attempted suicide, aggressive behavior, and schizophrenia with a serotonin $1 \mathrm{~B}$ receptor (A-161T) genetic polymorphism. Neuropsychobiology 2004;49:1-4.

48. Tyler WJ, Alonso M, Bramham CR, Pozzo-Miller LD. From acquisition to consolidation: on the role of brain-derived neurotrophic factor signaling in hippocampal-dependent learning. Learn Mem. 2002;9:224-37.

49. Spalletta G, Morris DW, Angelucci F, Rubino IA, Spoletini I, Bria P, et al. BDNF Val66Met polymorphism is associated with aggressive behavior in schizophrenia. Eur Psychiatry. 2010;25:311-3.

50. Chung S, Chung HY, Jung J, Chang JK, Hong JP. Association among aggressiveness, neurocognitive function, and the Val66Met polymorphism of brain-derived neurotrophic factor gene in male schizophrenic patients. Compr Psychiatry. 2010;51:367-72.

51. Guan X, Dong ZQ, Tian YY, Wu LN, Gu Y, Hu $Z Q$, et al. Lack of association between brain- derived neurotrophic factor Val66Met polymorphism and aggressive behavior in schizophrenia. Psychiatry Res. 2014;215:244-5.

52. Levin BL, Varga E. MTHFR: Addressing Genetic Counseling Dilemmas Using Evidence-Based Literature. J Genet Couns. 2016;25:901-11.

53. Dong ZQ, Tian YY, Guan X, Wu J, Gu Y, Hu $Z Q$, et al. Genetic polymorphism of methylenetetrahydrofolate reductase and risk of aggressive behaviour in schizophrenia. Psychiatry Res. 2012;200:1082.

54. Su L, Long J, Pan R, Xie X, Mao X, Zhou Y, et al. Influence of NRGN rs12807809 polymorphism on symptom severity in individuals with schizophrenia in the Han population but not the Zhuang population of south China. Acta Neuropsychiatr. 2015;27:221-7.

55. Ptácek R, Kuzelová H, Stefano GB. Dopamine D4 receptor gene DRD4 and its association with psychiatric disorders. Med Sci Monit. 2011;17:RA21520.

56. Suchanek-Raif R, Kucia K, Kowalczyk M, Raif P, Paul-Samojedny M, Fila-Daniłow A, et al. Association Study of Tumor Necrosis Factor Receptor 1 (TNFR1) Gene Polymorphisms with Schizophrenia in the Polish Population. Mediators Inflamm. 2017;2017:6016023.

\section{Genetski polimorfizmi serotoninskog i dopaminskog sustava u odnosu na nasilje i agresiju u shizofreniji}

Sažetak - Shizofrenija je kronična bolest, rekurentnog tijeka, koja u konačnici dovodi do propadanja kognitivnih i emocionalnih funkcija. lako etiologija same bolesti nije u potpunosti poznata, najvjerojatnije je multifaktorijalna, uz podjednaku važnost okolišnih i genetskih čimbenika. Premda većina psihijatrijskih pacijenata nije nasilna, dobro je poznata povezanost između shizofrenije i agresivnog ponašanja. Također je poznato da brojni psihološki i socijalni čimbenici utječu na pojavu nasilja u pacijenata sa shizofrenijom, ali je nedovoljno istražen utjecaj genetskih promjena i polimorfizama gena na pojavu nasilja u ovoj skupini pacijenata. Nasilje i agresija su kompleksan obrazac ponašanja što dovodi do poteškoća u usporedivosti genetskih studija i kliničkoj primjenjivosti istih. $U$ ovome radu su sistematizirano prikazana dostupna saznanja o potencijalnoj povezanosti polimorfizama gena s implikacijama na serotonergičko i dopaminergičko funkcioniranje i agresivnih simptoma te nasilnog ponašanja u shizofreniji.

Ključne riječi: dopamin, serotonin, genetski polimorfizam, agresija, nasilje 